\title{
Women, nation and voicing in Sharai Mukonoweshuro's Shona novels
}

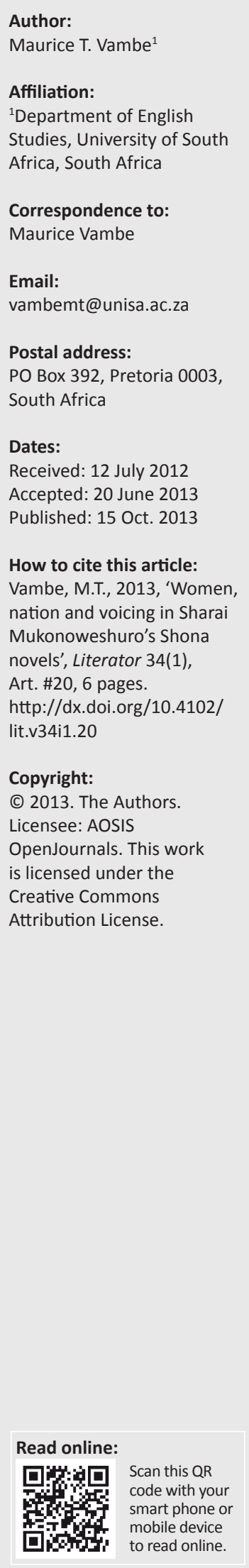

The article explores the fictional representation of women in two of Sharai Mukonoweshuro's novels, Akafuratidzwa Moyo and Ndakagara Ndazviona. Traditional Shona expectations of how a woman should behave have prescribed the roles that women are expected to play in society. In Southern Rhodesia (now Zimbabwe), colonialism invented customary laws in which women were further downgraded to social positions akin to those of minors. Although the nationalist struggle was essentially meant to guarantee freedom for all Black people irrespective of gender, the male elites constructed the identity of Black women as their inferior 'other'. Against this background this article argues that Sharai Mukonoweshuro's novels struggle against these male sanctioned stereotypes. However, as will be shown, Mukonoweshuro's mode of resistance to female stereotypes is ambivalent in the sense that the author constructs young women who defy patriarchy on the one hand and, on the other hand, old women who do the unthinkable act of poisoning their own sons.

Vroue, nasie en verwoording in Sharai Mukonoweshuro se Shona-romans. Die doel van hierdie artikel is om die fiktiewe voorstelling van vroue in twee van Sharai Mukonoweshuro se romans, naamlik Ndakagara Ndazviona en Akafuratidzwa Moyo, te verken. Tradisionele Shona verwagtinge van hoe 'n vrou moet optree, skryf die rolle voor wat van vroue verwag word om in die samelewing te speel. In 'n koloniale konteks soos die voormalige Rhodesië het kolonialisme wette in die gewoontereg bedink wat vroue verder gedegradeer het tot sosiale posisies soortgelyk aan dié van minderjariges. Hoewel die nasionalistiese stryd in wese bedoel was om vryheid te waarborg vir alle Swart mense, ongeag van geslag, het die manlike elites Swart vroue as hul minderwaardige 'ander' gekonstrueer. In hierdie artikel word geargumenteer dat Sharai Mukonoweshuro se romans worstel met hierdie manlik-goedgekeurde stereotipes. Maar, soos getoon word, Mukonoweshuro se wyse van weerstand teen vroulike stereotipes is ambivalent; die skrywer skep jong vroue wat die patriargie aan die een kant uitdaag, en aan die ander kant, ou vroue wat die ondenkbare doen om hulle eie seuns te vergiftig.

\section{Introduction}

\section{Women in male writings}

Shona traditional culture has prescribed roles for women. For example, in some versions of Shona culture (Chiwome, cited in Gaidzanwa 1996), a good woman is a stoic, self-effacing, loyal and biological mother. In her book, Images of women in Zimbabwean literature, Gaidzanwa (1985), analyses 14 novels in Shona and Ndebele literatures. Of these, only one is by a woman. Gaidzanwa accuses male writers of portraying women in what she terms passive and negative images of womanhood. These women appear in male fiction as stoic mothers, deceitful wives, gossipers, murderers and prostitutes. Such images are considered dangerous because they deny African women agency. According to Gaidzanwa (1985:8), 'the images delegitimise their [the women's] struggles for fundamental rights and freedom such as the right to education, jobs, health and other valued goods and services in society'.

If a woman behaves in a way that does not conform to and confirms these stereotypes, she is labelled a witch, prostitute and murderer. These definitions are meant to control not only the sexuality of Black women, but their social movements as well. The politics of presenting female characters is then not neutral. Boehmer (1992) observes that although women in male fiction command and occupy high statuses in symbolical representation, in real life they occupy the lowest rung of the social ladder. Whilst in traditional society Black women could be held as pawns and captives in war, under colonialism their situation worsened as they were downgraded to minors. Women were considered intellectually and morally weak, but sexually dangerous (Schmidt 1992). During the African people's liberation struggle in Southern Rhodesia (present-day Zimbabwe), the 
images of women in both the public and private spheres in the Shona society did not change significantly. Women were not only sexually exploited, but were also shown 'in action' mounting guns at camps - although most were not allowed to fight at the warfront (Nhongo-Simbanegavi 2000).

It is against this trying background that women such as Sharai Mukonoweshuro attempt to recreate social reality. Professional commitments, poverty and child rearing take time away from women. When women finally write, they find themselves and their work frowned upon by a dominant male literary tradition that has anointed itself as the canon. Stratton (1994) puts the predicament of female Black writers in Africa clearly when she complains that:

In characterizing African literature, critics have ignored gender as a social and analytical category. Such characterization operates to exclude women's literary expression as part of African literature. Hence what they define is the male literary tradition. (p. 1)

For Stratton, critical practice is not an innocent undertaking. It authorises particular vocabularies that can work to expand or narrow the range of creative possibilities for women's writings in Africa. Women writers have faced challenges of seeking to assail and transcend literary stereotypes of female characters in male fiction.

\section{Women, nation and literary voice}

Arising from the attempts by male writers to 'erase the female writer or character in fiction', suggestions have been made as to how to promote 'strategies of selving' (Boehmer 1992:9) for women writers. For Gunner, Chitauro and Dube (2001:133), the capacity for women to create a literature that society will listen to depends on 'their ability to mark out a path contrary to what the [male] stereotype demanded, chart a counter discourse, answer a master narrative' - a process that interlocks debates relating to empowerment, space, voice and identity. This would then enable women writers to project new identities. However, some feminists such as Nnaemeka (2007) have complicated this picture that suggests that when women write about women, they are inherently endowed with perceptions that always seek to liberate other women. Nhongo-Simbanegavi (2000) supports the view that sometimes ordinary women, and even female writers, are consciously and unwittingly made to write as women, but are still articulating the dominant male views which enjoin women to be loyal and to not question the unequal relations between men and women in society. This contradiction in the way women write about themselves is apparent in Mukonoweshuro's (1990) novel, Ndakagara Ndazviona.

\section{Ndakagara Ndazviona and ambivalent female response to patriarchy}

Ndakagara Ndazviona has a simple plot, which involves a young beautiful girl, Revai, who is enticed into a sexual liaison by her aunt's old husband, VaMhosva. Revai becomes pregnant and this angers her one-time high school lover, Jemisi. Jemisi hatches a plan to win Revai back, which involves stabbing VaMhosva to death. What follows is a tale of woe as Revai is thrown out of VaMhosva's home by the latter's brothers. Revai is deprived of VaMhosva's property which includes a cafe that she should have inherited. She is forced to take her baby boy, Tasara, to her rural home to stay with her parents. However, VaBhande, Revai's maternal uncle, takes her to town in the hope of finding a job for her. In the Highfield suburb of Harare (the novel was published in 1990, ten years after Salisbury had changed to Harare, hence the use of Harare), Revai meets Jemisi who makes her pregnant. The crisis emerges when Revai brings Tasara to where Jemisi is lodging. Jemisi does not want Tasara in his home because the baby reminds him of VaMhosva whom he killed. During the war of words that ensues between Revai and Jemisi, the latter takes a hoe and strikes Revai on the head. Even though Jemisi is arrested, at the end of the novel Revai blames herself and pledges to forgive Jemisi and become his wife once he is out of jail. The author invests Revai with qualities such as physical beauty, sensuousness, stoicism, self-effacement, victimhood and deceitfulness. When the reader first meets Revai, her mother, VaRegedzai, is trying to persuade her to marry VaMhosva. Revai's mother sees potential wealth coming into her home from such a union:

VaMhosva vakubvuma woziva kuti wagarika mwana wangu. Haisi fuma yavainayo, mombe, mbudzi, huku ifararira. Futi ndakanzwa kuti vari kuvakisa kefa pajakata. Zvingwa ungaita zvokuvata wakatsamira. [If Mr Mhosva accepts you as a wife, know my child that you are sitting pretty. He has cattle, goats and chickens. I also heard that he is building a café at Jakata. You will really sit pretty.] (Mukonoweshuro 1990:16, [author's own translation])

VaRegedzai is responding to the necessity of economic and material security whilst the reader sees her pushing her own daughter into a polygamous relationship. What is striking here is that VaRegedzai - a woman - as well as Revai herself, is working to undermine VaMhosva's stable relationship with his wife, VaMandinika. Although Mai Rudo (VaMhosva's wife) does not quit, discord has been sown between VaMandinika and Revai. VaMandinika responds with characteristic anger to the marital coup. The worrying issue is that the writer has not moved away from stereotypical images of women as human beings who destroy each other's families. Also, though we read that Revai is now staying with VaMhosva, Jemisi still comes to visit her. On one such occasion, Revai and Jemisi are almost caught redhanded by VaMhosva before Revai helps Jemisi to escape. The picture that is being painted of Revai is one of marital infidelity.

Revai is depicted as being deceitful, and as the one who encourages Jemisi to visit her. She also conceals Jemisi's romantic moves from VaMhosva. In fact, Revai still addresses Jemisi as her lover, despite the fact that at one time, Jemisi almost raped her even though at the time, she was still VaMhosva's wife. It is possible to argue that there is deep love between Revai and Jemisi despite Revai's marriage to VaMhosva. As Jemisi himself says: 
Rudo kana rwabata munhu haazozivi zvaanoita ... Ndiyo mhosva muchindiona ndakadai izvi nhasi Uno. Rudo ndirwo rwakandipinza mungozi ino). [When one falls in love, one is confused ... That is why you see me in this problem of having overreacted (by killing VaMhosva).] (Mukonoweshuro 1990:130, [author's own translation])

Jemisi justifies killing VaMhosva by suggesting that he was overpowered by emotions. As he confesses, 'Ndiyo mhosva ndakauraya VaMhosva' [That is why I killed VaMhosva] (Mukonoweshuro 1990:119, [author's own translation]).

However, Revai cannot understand why Jemisi had to commit murder in order to express his love for her. When Jemisi realises that Revai is going to the police, it is then that he strikes Revai on the head with a hoe. The irony is that despite the fact that Jemisi almost murdered her, Revai feels pity for him and would want to forgive him. As the narrator says:

Revai akatanga kunzwira Jemisi urombo. 'Ini ndini ndakakanganisa', akadaro achipukuta misodzi pamatama. 'Dai ndakanga ndisina kumbotorana naVaMhosva nhamo yese iyi pangadai pasina. Jemisi haana mhosva. Mhosva ndeyangu.' [Revai began to feel pity for Jemisi. 'I am the one who was wrong', she said wiping tears off her cheeks. 'If I had not associated with $\mathrm{Mr}$ Mhosva, there would have been no problem. Jemisi has no crime that he committed. I am the source of the problem.'] (Mukonoweshuro 1990:136, [author's own translation])

In this passage, Revai is portrayed as unthinking and selfincriminating. She condemns herself for the mishaps in her life. In the process she absolves VaMhosva who raped her and forced her into a loveless marriage. Revai also absolves Jemisi from blame for killing Vamhosva. And, lastly, Revai also blames herself for 'angering' Jemisi who nearly murdered her using a hoe. At this point in the narrative, the reader feels that the writer has undermined Revai's struggle to determine whom she must love. The author has created in Revai an ambivalent image of a Black woman who can love deeply, is deceitful, but forgiving to the man who poses a physical threat to her life. This string of negative images used to depict Revai's different emotional states reinforces the patriarchal images of women as treacherous and morally weak. What Revai's speech does to the whole story is to endorse a conception and perception by African men of Black women as marginal and inconsequential to the life of the nation. This subverts women's efforts to empower themselves and to contribute towards nation building. Sharai Mukonoweshuro's attempt to recreate social reality ironically undercuts the efforts of Black women in real life. Unwittingly, the author's negative portrayal of women like Revai challenges feminist critics such as Gaidzanwa who believe that women's writing is necessarily and inherently progressive in the ways that images of women and nation are composed. In Mukonoweshuro's creative imagination, female characters are coterminous with the nation in so far as they represent the underside or the negative forces of that nation.

At the end of the novel in question, even educated women such as Dambudziko, who is a nurse, and is supposed to have critical consciousness as regards women's rights, works hard to persuade Revai to believe that Jemisi, a potential murderer, is the person who can make Revai happy. It can be argued that through Dambudziko, the writer suggests that some women work hard to persuade other women that being subordinate to men is natural. Dangarembga's (1987) Nervous conditions depicts a similar condition of nervousness in women like Tambudzai's mother who enjoins Tambudzai to get married and not to question inequalities within the marriage institution. In other words, Mukonoweshuro could be understood to be arguing against this cultural status quo. This depiction is, however, not critically contested in the novel and the reader is left with the impression that the author subscribes to the notion that a woman is 'complete' when she is married to some man, no matter how bad the situations in the marriage are. In fact, at the end of the novel, Revai goes to Rafamwoyo, Jemisi's home.

Readers may feel that the novel has slotted negative images of womanhood into a patriarchal paradigm without questioning the assumptions underlying the system of negative signification. Readers may also feel that a novel in which a woman chooses death instead of life, thereby undercutting the very indigenous culture that women have to preserve, perpetuate and promote as the basis of a transformed African culture, is perpetuating antisocial attitudes. This ambivalent depiction of female characters might even go to show not only the extent to which negative Shona attitudes have shaped the creative sensibilities of the author, but also how they have constrained her from experimenting with positive images of womanhood. In fact, until 1980 when Zimbabwe gained independence from Britain, 'all African women, married or unmarried, were perpetual minors, always under the guardianship of their fathers, their husbands, or some male relative' (Stewart, Ncube \& Armstrong 1990:170). But this point does not mean that female writers cannot rise above the descriptions of women in populist law made by patriarchy for the preservation of the institution where men rule women.

Another way of reading this novel is to discuss the contradictions of the representation of gender in nationalism. Whilst analysing the characterisation of Black women in male African literature, Stratton (1994:4) observes that the unequal relations between men and women in real life are reproduced at a symbolical level in African literatures. In Senghorian terms, the mother figure is represented as nourishing and caring, yet in real life the same woman is wearing tattered clothes, hungry and at times violated sexually by the same men who raise her status through this symbol. Shona society depicted in Ndakagara Ndazviona (Mukonoweshuro 1990) emphasises female conformity to the rule of men. It is thus an act of transgression when Revai resists her family and Shona society by having a secret love relationship with Jemisi even when she has a baby and is living with VaMhosva. By this gesture of rebellion, Revai has turned her back on some Shona customs which force young girls to marry men old enough to be their fathers. Schmidt (1992), who writes on the history of the Shona women before and during colonialism, 
states that young women who felt coerced into unwanted and loveless marriages often resisted in ways that registered their discontent. Resistance took the form of running away with young men or, if still cohabiting within the arranged marriage contract, denying the old man sexual favours. In Ndakagara Ndazviona (Mukonoweshuro 1990), the irony is that the same rebellious Revai is prepared to sacrifice her life when she chooses to live with Jemisi who nearly killed her. That might be the author's attempt to direct the reader to the complexity of the character of Revai. This ambivalent mode of survival under patriarchy is radically expanded in Akafuratidzwa Moyo (Mukonoweshuro 1983) in which a woman takes the shocking decision to poison her son, just because he is too loyal to his wife to the point of denying his mother the niceties she used to enjoy before his marriage.

\section{Murderous women: Akafuratidzwa Moyo}

The idea that some feminist critics who push for the recognition of women's rights sometimes make large claims for the freedom of women can be tested in Akafuratidzwa Moyo (Mukonoweshuro 1983). This novel has a simple plot that raises fundamental issues about changes in Shona society that are becoming increasingly materialistic. In the novel, VaMakandionei complains that her daughter-in-law has all the qualities deplored in the Shona culture: unodada [she wants to show off] (Mukonoweshuro 1983:4), and ... kunyima [she is mean], usimbe [she is lazy], ufeve [she has loose morals], ndipo pamusha pazvo [she has all the negative attributes] (Mukonoweshuro 1983:6). The communal ethos of spontaneous sharing is under siege. As a result, the likes of Svinurai, though employed, are forced to focus on satisfying the material needs of the nucleus family. He can only help the extended family to a limited extent. Mukonoweshuro (1983) therefore makes the vital observation that capitalism has cut the umbilical cord in the African family. VaMakandionei thinks that Machivei refuses to share the niceties that Svinurai brings home. One might argue that this tension-ridden relationship between the mother-in-law and her daughter-inlaw has precedence in African culture with the two women competing to control the son and husband, respectively.

In the novel in question, the undeclared war between mother-in-law and daughter-in-law leads to disastrous consequences. Seemingly fed up with what she perceives as Machivei's tight fist where money is concerned, VaMakandionei hatches a murderous plan to kill Machivei together with her children. VaMakandionei lights the fire that burns the house in which her son's family is sleeping, and feigns innocence. This murderous act serves to confirm the stereotypical perception of women as naturally destructive. Not only is VaMakandionei unhappy that her son's wife and children have not died in the inferno, she also resents the fact that Svinurai will not take action to divorce Machivei. In fact, VaMakandionei turns her anger against her son, whom she kills by poisoning his beer. It is possible here to suggest that colonial modernity has created tensions in the African family that manifest themselves through struggles to control the perceived benefits from colonialism. Unfortunately, the family is depicted as being ill-equipped to deal with the challenges of the new dispensation.

The general anti-social behaviour of VaMakandionei, ironically finds sympathy in critics such as Gaidzanwa (1985:13), who argues unconvincingly that 'the kinds of calculations and choices that the woman creates are the mark of liberation and freedom' (author's emphasis). VaMakandionei's 'calculations' and 'choices' are not an indication of liberation and freedom but of moral degeneration. They are a mark of irresponsibility which has contributed to the unfortunate perception that all women are dangerous. Writing about women is perceived as dangerous in male nationalist discourses. Gunner et al. (1994) distinguish the dangerous woman who is destructive in the reckless sense, from the dangerous woman who destroys in order to re-vision a new way of life when the critics say:

They were dangerous and that is why man both feared and wished to control them. They were perceived as dangerous in that they might influence other women to follow their lifestyles as they were often single and divorced women. The sense of danger was also connected with a sense of their ability to revision through their expressive art. They could both reshape and control in a way that was otherwise not possible. This notion of power relates to the acceptance in many African societies of licence, in some situations, within song and poetry - that singers may tell terrible things in song and poetry, say out what is not usually heard and survive with impunity. (p. 118)

VaMakandionei is neither a singer nor an artist of any sort. Her actions are motivated by possessiveness, envy and greed. The actions confirm the patriarchal image of women as being violent, deceitful and dangerous and, therefore, constantly needing to be monitored and morally guided by men. Women such as VaMakandionei, therefore provide justification for the indiscriminate arrest of Black women in the early eighties and nineties as principal offenders in family murders that involved sexual liaisons.

It is also possible to suggest that in creating a character as evil as VaMakandionei, the author does not wish to condone violence of any kind, whether perpetrated on women by another woman or on women by men. This is evidenced by the fact that at the end of the novel, VaMakandionei hangs herself. If credit is due to the author, it is because she has created a memorable negative character who becomes in Zimbabwean literature the archetype of what a woman should never be. Considered in this vein, through the character of VaMakandionei, the author could be suggesting that the traditional Shona society, built on traditional expectations of communal solidarity, is bound to implode or snap when confronted by a virile material acquisitiveness introduced by colonialism. The author could also be suggesting that although Zimbabwe has gone through two (now three) Chimurenga struggles there has not been a qualitative change in ordinary women's lives on a cultural level.

In feminist criticism such as one evidenced by Gaidzanwa (1985), women who rebel and those who kill for whatever 
reason are potential makers of history. The ideological standpoint raises moral concerns about the fundamental motivation, interests and end result of killing. When is killing justified? Akafuratidzwa Moyo (Mukonoweshuro 1983) was published in the 1980s when the discourse of women's liberation and rights was firmly entrenched and promoted by women themselves. The irony is that the author's repertoire of images of women murderers, who are motivated by envy, is limited, and this tends to undermine her desire to represent women as carriers of progressive aspects of feminism.

Mukonoweshuro's (1983) images of potential womanhood give the impression that she is confirming the male idea that women need to be under the perpetual guidance of men. However, due to changes that have taken place in women's lives, this portrayal does not correspond to the realities of women in present-day Zimbabwe. Put differently, Mukonoweshuro writes in a way that confirms some negative stereotypes typical in the fiction of some Shona male authors (Gaidzanwa 1985). This observation would then suggest that although Black women writers can, and do indeed participate in narrating the nation, it is not a given that what they write and the images they authorise necessarily shake the discriminatory foundations of patriarchy. In fact, female authors like Mukonoweshuro have consciously or unwittingly been co-opted by the dominant patriarchal order to muzzle and marginalise the potentialities of womanhood in fiction.

In other words, the voices of women authoring or authorising women is not a straightforward undertaking, but an arduous process which sometimes brings out unintended results. That is why it is difficult to agree with Stratton's (1994) overstatement on female writers' agency in her authoritative conclusions to her book, Contemporary African literature and the politics of gender where she argues that:

When women began publishing their work in the mid-sixties in Africa, they faced the problem of not only speaking for the experience of women in their own right ... but also of combating the orthodoxies of colonial and anti-colonial writing. (p. 173)

These sort of generalisations from established critics need to be questioned because the claims they make about Black women writers do not apply to all women writers. Women writers' consciousness is uneven in their handling of themes related to women's lives.

\section{Women and voicing the nation in indigenous languages}

As part of her desire to recreate social reality with women at the centre of her discourse, Mukonoweshuro (1990) has resorted to the use of the Shona language. Her Shona language in the two novels considered in this article is distinctively marked by the Karanga dialect of the people of the Masvingo Province in south-west of Zimbabwe. It is as if the author is making an intervention in the language debate in African literature. Some of the passages in Ndakagara Ndazviona are memorable because they are steeped in an idiom which the
Shona people in general, and the people of Masvingo in particular, are bound to identify as theirs:
'Unoda kuona kuti ndinodii nhai?Usatambe uchidaro.'
'Aizve hautendi nhai? Uchatenda waona SaTomasi.'
'Uchindiona kudai ndinotova nedumbu.'
'Ahii zvechokwadi chaizvo, ndarema ini.'
'Unofunga ndingatenda nhema dzakadaro?'
[(22) 'You want to see what I will do? Try to be serious.'
'Of course, you are not believing? You shall believe after seeing like the biblical Thomas.' 'As you see me I am pregnant.'
'It is true I am pregnant.'
'You think I will listen and believe that jest?'] (Mukonoweshuro 1990:15, [author's own translation])

This dialogue between Revai and Jemisi identifies Mukonoweshuro as a distict Shona author who can make allusion to the Bible as in 'Uchatenda waona SaTomasi' [You shall believe after seeing reality as Thomas did]. The author also blends the Shona idiom (Ndarema - [I am pregnant]) with modernist jargon (Ndingatenda nhema - [You think I will believe those lies]). But it seems that in Ndakagara Ndazviona and Akafuratidzwa Moyo the author has indulged in the use of the Shona language without some corresponding critical perspectives to question the female stereotypes that she creates and exposes. The use of indigenous languages on their own, without developing an expanded critical consciousness to interrogate the basis of social oppression, will not promote the very indigenous cultures that she wishes to advance.

\section{Conclusion}

The work of Sharai Mukonoweshuro, one of the few female Shona writers writing in the Shona language, has not received substantial critical analysis. She writes her novels under extreme conditions in which the images of women in fiction and in real life are negative due to a largely male-dominated literary tradition. After analysing Ndakagara Ndazviona and Akafuratidzwa Moyo, one detects a genuine desire by the author to push women's rights onto the public sphere. There is no doubt that the author's young female characters struggle in subtle ways against societal restrictions to achieve their freedom. There is also the question that in focusing on the politics of the domestic sphere, the author attempts to expand on the notion of national culture as rooted in the private and public experiences of the characters. By focusing on the conflicts that take place in the domestic sphere, the author also assails the male tradition whose conception of politics and resistance revolves around visible organised forms of political agency. But one also gets a sense that in an attempt to narrate the nation by giving voices to female characters, the author is entrapped in a male-dominated discourse of cultural nationalism the tendency of which is to objectify women. This article acknowledges open revolt by female characters against the Shona cultural norms which would have made women totally helpless under the domination of men, had they been allowed free space in the novel. The article also acknowledges the potential power that the patriarchal system has on female authors. Female authors such as Mukonoweshuro are sometimes undermined by male-driven values in society so much so, that women 
authors end up failing to recreate images of progressive women in creative works of art.

\section{Acknowledgements \\ Competing interests}

The author declares that he has no financial or personal relationships which may have inappropriately influenced him in writing this article.

\section{References}

Boehmer, E., 1992, 'Motherlands, mothers and nationalist sons: Representations of women in African Literature', in A. Rutherford (ed.), From commonwealth to post colonial, pp. 57-68, Dangaroo Press, Sydney.

Dangarembga, T., 1987, Nervous conditions, Zimbabwe Publishing House, Harare.

Gaidzanwa, R., 1985, Images of women in Zimbabwean literature, College Press, Harare.
Gunner, L., Chitauro, M. \& Dube, C., 2001, 'Song, story and nation: Women as singers and actresses in Zimbabwe', in L. Gunner (ed.), Politics and performance: Theatre, poetry and song in Southern Africa, pp. 63-84, Witwatersrand University Press, poetry and song in
Johannesburg.

Mukonoweshuro, S., 1983, Akafuratidzwa Moyo, Longman, Harare.

Mukonoweshuro, S., 1990, Ndakagara Ndazviona, Zimbabwe Publishing House, Harare.

Nnaemeka, O., 2007, 'Bringing African women into the classroom: Rethinking pedagogy and epistemology', in T. Olaniyan \& A. Quayson, (eds.), African literature: An anthology of criticism and theory, pp. 570-577, Blackwell, London.

Nhongo-Simbanegavi, J., 2000, For better or worse? Women and Zanla in Zimbabwe's liberation struggle, Weaver Books, Harare.

Schmidt, E., 1992, Peasants, traders and wives: Shona women in the history of Zimbabwe 1870-1939, Baobab Books, Harare.

Stewart, J., Ncube, W. \& Armstrong, A., 1990, 'The legal situation of women in Zimbabwe', in J. Stewart, W. Ncube \& A. Armstrong, (eds.), Southern Africa: The legal situation of women in Southern Africa, pp. 5-26, University of Zimbabwe Publications, Harare.

Stratton, F., 1994, Contemporary African literature and the politics of gender, Routledge, London. 